\title{
CORRELATION BETWEEN COVERAGE OF BCG IMMUNISATION AND HEALTHY HOUSES WITH FINDINGS OF PAEDIATRIC TUBERCULOSIS
}

\author{
Korelasi Cakupan Imunisasi BCG, Rumah Sehat dengan Penemuan Tuberkulosis Anak
}

\author{
Melisa Ambarwati \\ Public Health Faculty, Universitas Airlangga, melisa.ambarwati-2015@fkm.unair.ac.id \\ Corresponding Author: Melisa Ambarwati, melisa.ambarwati-2015@fkm.unair.ac.id, Departement of \\ Epidemiology, Public Health Faculty, Universitas Airlangga, Dr. Ir. H. Soekarno, Mulyorejo, Surabaya City, \\ East Java, Indonesia, Code Pos 60115
}

\section{ARTICLE INFO \\ Article History: \\ Received April, $9^{\text {th }}, 2019$ \\ Revised form June, $25^{\text {th }}, 2019$ \\ Accepted September, 27 $7^{\text {th }}, 2019$ \\ Published online September, $30^{\text {th }}$, 2019}

\author{
Keywords: \\ tuberculosis; \\ healthy house; \\ bacille calmette-guérin; \\ east java
}

\section{Kata Kunci:}

tuberkulosis;

rumah sehat;

bacille calmette-guérin;

jawa timur

\begin{abstract}
Background: Tuberculosis in children is still found in East Java Province at 2017 with 2,749 cases of paediatric tuberculosis. The Bacille Calmette-Guérin (BCG) immunisation coverage and healthy houses in East Java Province increase every year. Purpose: This study aims to analyse the correlation between BCG immunisation and healthy houses with paediatric tuberculosis discovery in East Java Province during 2015-17. Methods: This study is observational with a correlation study design. The population in this study were children aged 0-14 years who suffered from tuberculosis in a district or city in East Java Province in 2015-17. Sampling of this study uses aggregate data on paediatric tuberculosis discovered in children aged 0-14 years, coverage of BCG immunisation and coverage of healthy houses in districts/cities in East Java in 2015-17 found in Health Profile of East Java Province 2015-17. The variables studied were paediatric tuberculosis in children aged 0-14 years, BCG immunisation coverage and healthy house; the analysis techniques were the Kolmogorov-Smirnov normality test and Pearson correlation. Results: This study shows that there is correlation between BCG immunisation and paediatric tuberculosis $(\mathrm{p}=0.01, \mathrm{p}$ $<0.05$ ) with a correlation value of 0.67 , indicating a strong and positive correlation. The results also show that there is a correlation between healthy houses and children with tuberculosis $(\mathrm{p}=0.01, \mathrm{p}$ $<0.05$ ) with a correlation value of 0.63 , indicating a strong and positive correlation. Conclusion: BCG immunisation coverage and healthy houses are positively correlated with paediatric tuberculosis discovered in East Java district/city.
\end{abstract}

C2019 Jurnal Berkala Epidemiologi. Published by Universitas Airlangga.

This is an open access article under CC-BY-SA license (https://creativecommons.org/licenses/by-sa/4.0/)

\begin{tabular}{l} 
ABSTRAK \\
Latar Belakang: Tuberkulosis pada anak masih banyak ditemukan di \\
Provinsi Jawa Timur dengan jumlah kasus tuberkulosis anak sebesar \\
2.749 penderita. Cakupan imunisasi Bacille Calmette-Guérin (BCG) \\
dan rumah sehat di Provinsi Jawa Timur terus mengalami \\
peningkatan setiap tahunnya. Tujuan: Penelitian ini bertujuan untuk \\
\hline
\end{tabular}


menganalisis hubungan antara cakupan imunisasi BCG dan rumah sehat dengan penemuan tuberkulosis anak di Provinsi Jawa Timur selama tahun 2015-2017. Metode: Penelitian ini merupakan penelitian observasional dengan desain studi korelasi. Populasi pada penelitian ini adalah semua anak usia 0-14 tahun yang menderita penyakit tuberkulosis di tiap kabupaten/kota di Provinsi Jawa Timur pada tahun 2015-2017. Pengambilan sampel penelitian ini menggunakan total sampling pada data sekunder yang terdapat di Profil Kesehatan Provinsi Jawa Timur Tahun 2015-2017. Variabel yang diteliti adalah penemuan tuberkulosis anak pada usia 0-14 tahun, cakupan imunisasi BCG, dan cakupan rumah sehat tiap kabupaten/kota di Jawa Timur dalam tahun 2015-2017. Penelitian ini menggunakan teknik analisis yaitu uji normalitas dengan uji kolmogorov smirnov dan uji korelasi pearson. Hasil: Penelitian ini menunjukkan bahwa terdapat korelasi positif yang cukup kuat antara cakupan imunisasi BCG dengan penemuan TB anak ( $p=0,01$, $p<0,05 ; r=0,67)$. Hasil penelitian juga menunjukan bahwa ada korelasi positif yang cukup kuat antara cakupan rumah sehat dengan penemuan TB anak ( $p=0,01, p<0,05 ; r=0,63)$. Kesimpulan: Cakupan imunisasi BCG dan rumah sehat berkorelasi positif dengan penemuan TB anak per kabupaten/kota di Jawa Timur.

(C2019 Jurnal Berkala Epidemiologi. Penerbit Universitas Airlangga. Jurnal ini dapat diakses secara terbuka dan memiliki lisensi CC-BY-SA (https://creativecommons.org/licenses/by-sa/4.0/)

\section{INTRODUCTION}

Tuberculosis (TB) is one of 10 serious diseases that have the potential to cause death. The tuberculosis transmission agent is the bacterium Mycobacterium tuberculosis, which attacks human organs and mostly attacks the lungs (East Java Provincial Health Office, 2018). In addition to focusing on reducing the incidence of $\mathrm{TB}$, the Indonesian Government is focused on reducing stunting and increasing the percentage and quality and quantity of BCG immunisation. Tuberculosis often attacks sufferers in susceptible populations and in communities with low economies (Ministry of Health RI, 2018). Patients with tuberculosis in 2017 consisted of 5.82 million men and 3.24 million women; 1 million of them were children (WHO, 2018).

The World Health Organization (WHO) has listed the countries with the highest burden of tuberculosis (HBC). There are three HBC criteria - TB, TB-HIV, and MDR-TB - and there are currently 48 countries included in the HBC list. Indonesia, along with 13 other countries, has been included in the HBC list, which means that Indonesia has major problems in dealing with tuberculosis (Ministry of Health RI, 2018). TB prevalence research also shows TB rates with positive bacteriological testing at 759 per 100,000 population at $\geq 15$ years of age and 257 per 100,000 population at $<15$ years of age (Ministry of Health RI, 2018).

The Strategic Plan (Renstra) of the Ministry of Health in 2015-19 stipulated 16 main indicators and implementation related to the prevention and reduction of tuberculosis case load, including $80 \%$ coverage of child tuberculosis case findings, and $50 \%$ coverage of children aged less than 5 years receiving preventive treatment with isoniazid (PP INH) (Ministry of Health RI, 2013). Research that continued to be developed every year about paediatric tuberculosis, especially in developing countries, stated that paediatric tuberculosis needed to get the attention of health workers in order for them to make efforts to prevent and overcome the burden of paediatric tuberculosis (Sejati \& Sofiana, 2015). Paediatric tuberculosis is a tuberculosis disease that attacks children aged 0 14 years (Ministry of Health RI, 2013). Children infected with tuberculosis have a higher risk of suffering from severe tuberculosis such as miliary tuberculosis and tuberculosis meningitis, which has the potential to cause disability or death (Triharinni \& Isvandiari, 2014).

Adult tuberculosis and tuberculosis in children have the same risk of transmission, namely the duration of exposure, the level of transmission, and the individual immune system 
(Ministry of Health RI, 2013). Risk factors for someone likely to suffer from tuberculosis are a condition of immunity or weak body resistance, someone with HIV disease, someone with diabetes mellitus, direct contact with TB sufferers, poor nutrition, poverty, and poor housing conditions (Budi, Ardillah, Sari, \& Septiawati, 2018).

East Java Province has the second-highest number of tuberculosis sufferers in Indonesia. The total number of tuberculosis cases found in 2017 was 54,811 , of which 26,152 cases were positive for smear-positive TB. In 2017 the highest case of tuberculosis in children in East Java Province was found in Surabaya with 363 cases (East Java Provincial Health Office, 2018).

Vaccination, commonly known as immunisation, is a preventive effort carried out with the aim of providing immunity or protection against dangerous diseases or germs (Ministry of Health RI, 2013). Immunisation is an activity or effort to provide immunity intentionally, usually in infants or children, as a primary prevention effort to avoid infectious diseases, so as to reduce the incidence of infection, disability, and death (Susanto, Wahani, \& Rompis, 2016). Vaccination given to prevent tuberculosis is the Bacillus Calmette-Guerin (BCG) vaccine, which consists of weakened Mycobacterium bovis (Rosandali, Aziz, \& Suharti, 2016). BCG immunisation has an effectiveness of $50-80 \%$ in preventing pulmonary tuberculosis in the adult and children groups (Yani, Fauzia, \& Witdiawati, 2018).

The trend of coverage of BCG immunisation in Indonesia over the three years 2015-17 seemed constant, because coverage of BCG immunisation had been above $89 \%$, while the trend in the number of new cases of smear tuberculosis + $($ BTA +$)$ children aged 0-14 years had decreased, although not by much (Ministry of Health RI, 2013). Data on coverage of BCG immunisation in East Java Province in 2017 showed that the number of babies who had been immunised was 584,211 (101.52\%) (East Java Provincial Health Office, 2018).

The causative agent of tuberculosis is Mycobacterium tuberculosis, which is transmitted through the air and spreads through tiny splash particles (droplet nuclei) when coughing, sneezing, speaking, and etc (Triharinni \& Isvandiari, 2014).

The environment is a place where living things breed and the environment that influences the spread of tuberculosis is lighting, physical condition of the house, temperature, floor, humidity of the walls, and occupant density (Budi, Ardillah, Sari, \& Septiawati, 2018). A healthy house is a place to live that has adequate health requirements, including components of the house, sanitation facilities, and behaviour - i.e. healthy houses have healthy toilets, landfills, clean water facilities, waste water disposal facilities, good ventilation, suitable residential density, and a house floor that is not made of earth, and the occupants of the house practise hygiene (East Java Provincial Health Office, 2018)

Based on the problems presented previously, the author was interested in researching the correlation between coverage of BCG immunisation and healthy houses with the findings of paediatric tuberculosis in East Java Province in 2015-17, and then presenting an analysis.

\section{METHODS}

This study is an analytic observational study with a correlation study design. The unit of analysis in this research was aggregate data from each district/city in East Java. This research used the total population of the research population, namely children aged $0-14$ years who have tuberculosis. The data used are secondary data on the Health Profile of East Java Province in 20152017 contained in the East Java Provincial Health Office.

The variables researched in this study consisted of the dependent variable - namely, the findings of paediatric tuberculosis aged $0-14$ years recorded in each district/city in East Java - and the independent variables, which were the coverage of BCG immunisation and the coverage of healthy houses in East Java districts/cities in 2015-17.

This research described the findings of paediatric TB, coverage of BCG immunisation and coverage of healthy houses with a black-and-white graded map by dividing four quartiles with the same mean - black meant very high, dark grey meant high, light grey meant medium, and white meant low. The coverage of paediatric TB findings was the total number of paediatric TB cases found among the estimated number of paediatric TB cases that exist in an area within a certain period (Ministry of Health RI, 2013).

This research analysed the dependent variable and independent variables by conducting the Kolmogorov Smirnov normality test; then a correlation test was done to analyse the correlation between the dependent variable and the independent variables using the Pearson correlation test. 


\section{RESULTS}

Description of TB Findings in Children Aged 014 Years, Coverage of BCG Immunisation, and Healthy Houses in Every District/City in East Java Province in 2015-17

The findings of TB in children during the three years 2015-17 have fluctuated. Tuberculosis in children in 2016 increased from 1,895 to 3,382 cases and again declined in 2017 to 2,749 cases (Table 1).

The coverage of BCG immunisation in East Java Province during the three years 2015-17 experienced a significant increase. The 2016 coverage of BCG immunisation in East Java increased from $9.99 \%$ to $96.60 \%$ and increased again to $101.52 \%$ in 2017. Coverage of BCG immunisation increased dramatically in 2017 with $50 \%$ coverage already fulfilled in various districts/cities in East Java Province. Coverage of healthy houses in East Java Province in the three years 2015-17 fluctuated. In 2017 there were $7,129,501(69.34 \%)$ healthy houses of all houses in East Java Province (Table 1).

The results showed that, based on the findings of cases of TB in children in East Java Province, there were 2 districts/cities in the very high category, 2 districts/cities in the high category, 26 districts/cities in the moderate category and 8 districts/cities in the low category. The highest finding of paediatric TB in 2017 was in Surabaya City with 363 cases; the lowest finding was in Pacitan District, Magetan District, and Batu District by 2 cases (Figure 1).
Table 1

Findings of TB Cases in Children Aged 0-14 Years, Coverage of BCG Immunisation and Healthy Houses in East Java Province over the Three Years 2015-17

\begin{tabular}{lr}
\hline \multicolumn{1}{c}{ Variable } & Total \\
\hline Paediatric TB Aged 0-14 Years & \\
2015 & 1.895 \\
2016 & 3.382 \\
2017 & 2.749 \\
Coverage of BCG Immunisation & \\
2015 & $9,99 \%$ \\
2016 & $96,60 \%$ \\
2017 & $101,52 \%$ \\
Coverage of Healthy Houses & \\
2015 & $69,11 \%$ \\
2016 & $63,34 \%$ \\
2017 & $69,34 \%$ \\
\hline
\end{tabular}

The results showed that based on coverage of BCG immunisation in East Java Province there were 9 districts/cities in the very high category, 10 districts/cities in the high category, 10 districts/cities in the moderate category, and 9 districts/cities in the low category. Jombang District had coverage of almost 100 per cent. The lowest coverage of BCG immunisation in 2017 was Magetan District (4.40) (Figure 2).

The results showed that, based on the coverage of healthy houses in East Java Province, there were 9 districts/cities in the very high category, 10 districts/cities in the high category, 10 districts/cities in the moderate category, and 9 districts/cities in the low category. The highest coverage of 5 districts/cities in 2017 was Batu City (96.84\%), while the lowest coverage of healthy houses in 2017 was Sampang District (25.08\%) (Figure 3).
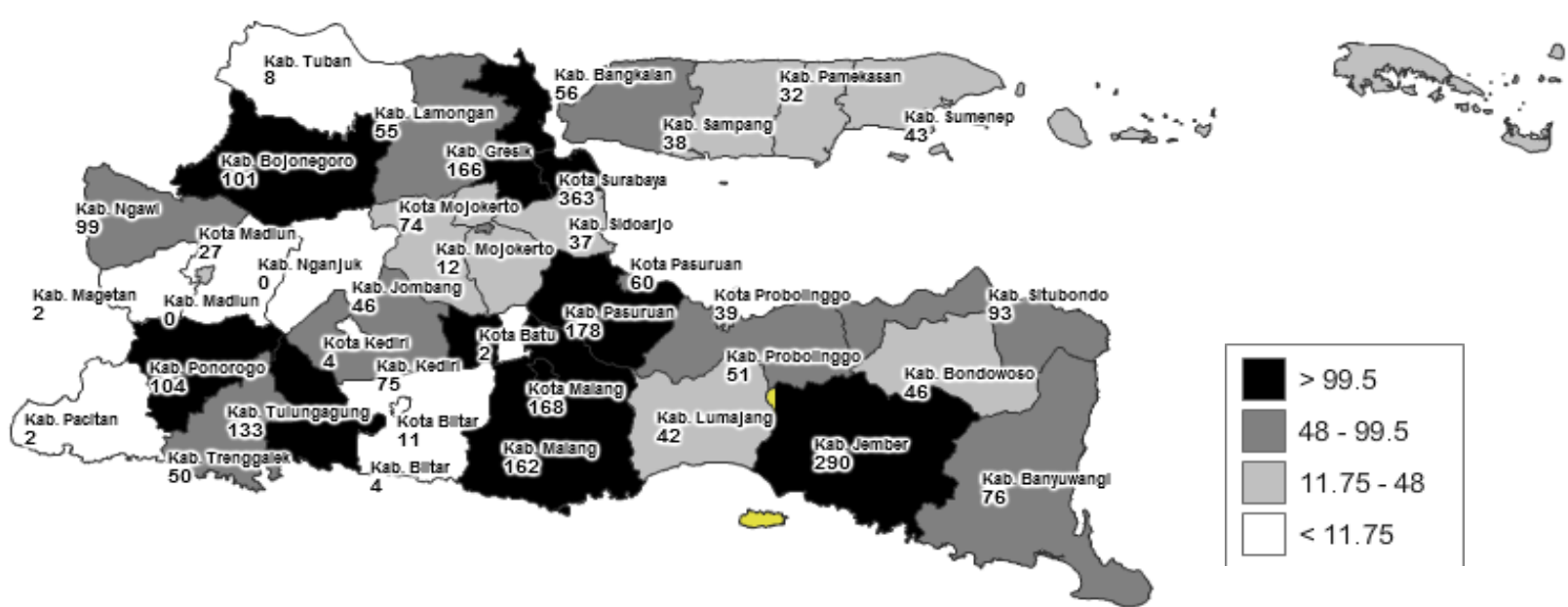

Figure 1. Distribution Map of Findings of Paediatric Tuberculosis in East Java Province in 2017 


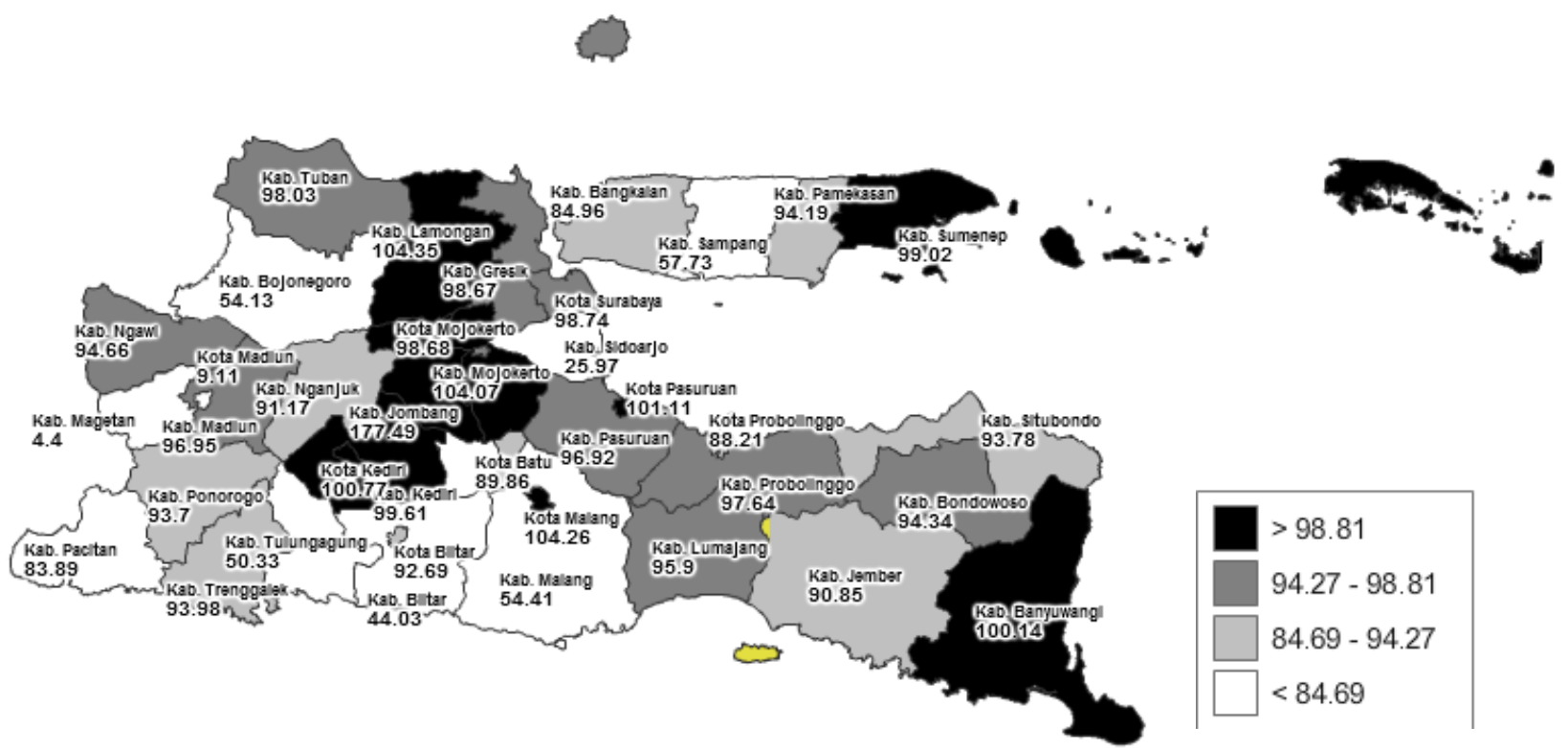

Figure 2. Distribution Map of Coverage of BCG Immunisation in East Java Province in 2017

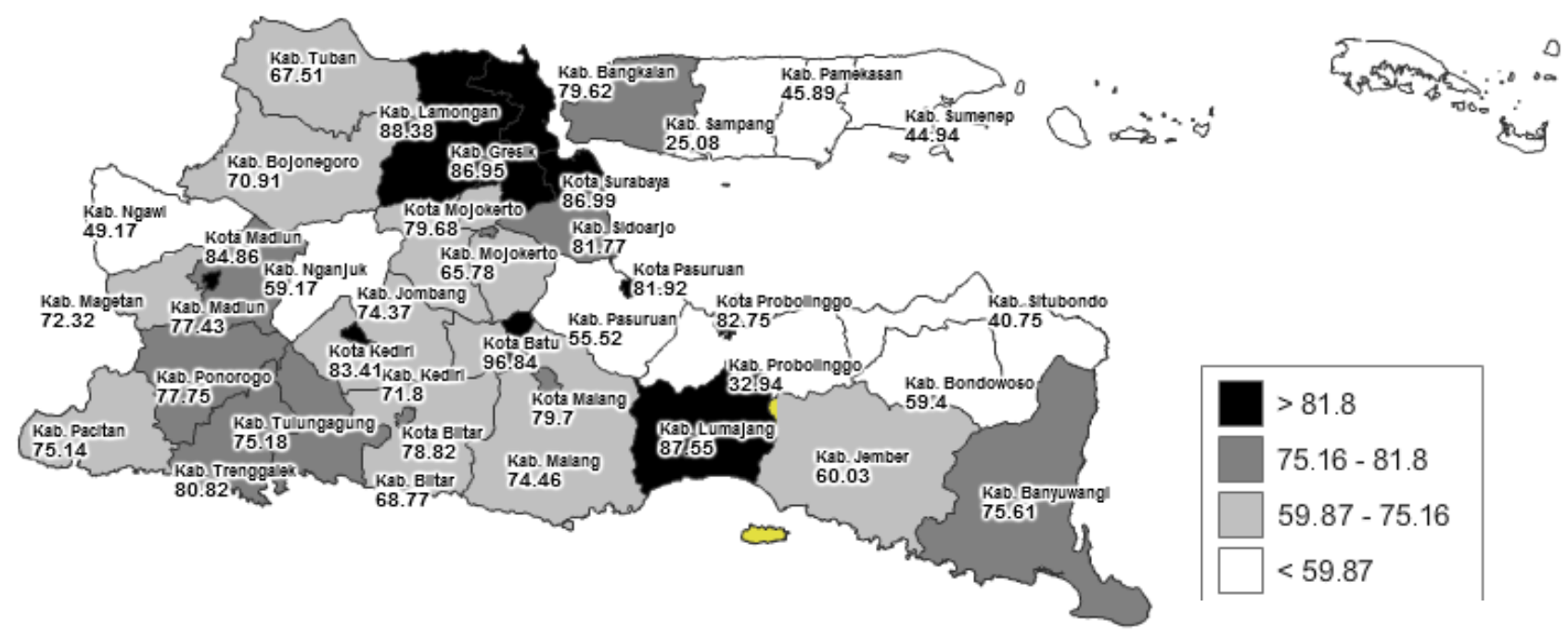

Figure 3. Distribution Map of Coverage of Healthy Houses in East Java Province in 2017

Correlation Analysis between Coverage of BCG Immunisation, Coverage of Healthy Houses with Findings of Paediatric Tuberculosis Aged 0-14 years in East Java Province in 2015-17

This research used correlation analysis (i.e. Pearson correlation test) to analyse the correlation between coverage of BCG immunisation and coverage of healthy houses with the findings of paediatric tuberculosis aged $0-14$ years in each district/city in East Java Province in 2015-17. The assumption that must be fulfilled first in Pearson correlation is that the error is normally distributed. A statistical test that can determine whether the error of data is normally distributed is the
Kolmogorov Smirnov statistical test. The results of the Kolmogorov Smirnov normality test on the coverage of $\mathrm{BCG}$ immunisation resulted in a significance value of $p=0.48 ; p>0.05$, meaning that the data were normally distributed and assumptions were fulfilled to further carry out the Pearson correlation test (Table 2).

The results of the normality test on the coverage of healthy houses variable resulted a significance value of $p=0.57 ; p>0.05$. It can be interpreted that the data distribution was normal and assumptions were fulfilled for the next analysis using the Pearson correlation test (Table $2)$. 
The results of the normality test on the paediatric tuberculosis aged $0-14$ years variable resulted in a significance value of $\mathrm{p}=0.12 ; \mathrm{p}>0.05$; then the data were normally distributed and assumptions were fulfilled for the next analysis using Pearson correlation test (Table 2).

Table 2

Normality Test Results of Coverage of BCG Immunisation, Coverage of Healthy Houses, and Findings of Paediatric Tuberculosis Aged 0-14 Years

\begin{tabular}{lr}
\hline \multicolumn{1}{c}{ Category } & \multicolumn{1}{c}{ Results } \\
\hline BCG Immunisation & 38 \\
N & 0,84 \\
Kolmogorov-Smirnov Z & 0,48 \\
Asymp. Sig.(2-tailed) & \\
Healthy Houses & 38 \\
N & 0,78 \\
Kolmogorov-Smirnov Z & 0,56 \\
Asymp. Sig.(2-tailed) & \\
Paediatric TB Aged $\quad \mathbf{0 - 1 4}$ & \\
Years $\quad$ Nolmogorov-Sminrnov Z & 1,19 \\
N & 0,11 \\
Kolmp.Sig.(2-tailed) & \\
\hline
\end{tabular}

The author also identified the pattern of correlations that affect inter-location as a spatial correlation by looking at the Morans I correlation value. At the Morans I value of 0.46 where $p$ value $>\square$ with $\square=0.05$, Ho was accepted, meaning that there was no spatial correlation between regions, so spatial testing could not be done. The next step was to analyse the correlation using Pearson correlation statistics test in paediatric tuberculosis aged $0-14$ years with BCG immunisation. Pearson correlation test results showed that the significance value of $\mathrm{p}=0.01$ where $\mathrm{p}$ value $>\square$ with $\square=$ 0.05 , which meant that there was a correlation between BCG immunisation with paediatric TB in East Java Province in 2017. The correlation strengths on BCG immunisation and paediatric tuberculosis aged $0-14$ years variables showed a Pearson correlation value of 0.67 , which meant that the correlation between paediatric tuberculosis aged 0-14 years with BCG immunisation was strong. The strength of this correlation indicated that increasing BCG immunisation was positively correlated with the increase in tuberculosis case findings in children (Table 3 ).

The results of the analysis of the correlation with the Pearson correlation test for paediatric tuberculosis aged $0-14$ years with healthy houses, found that the significance value was $\mathrm{p}=0.01$ where $\mathrm{p}$ value $>$ value with $\square=0.05$, which meant that there was a correlation between paediatric tuberculosis aged 0-14 years with healthy houses in East Java Province in 2017. The statistical test results between paediatric tuberculosis aged $0-14$ years with healthy houses obtained a Pearson correlation value of 0.63 , which meant that the correlation between paediatric tuberculosis aged 0-14 years with healthy houses was strong. The strength of this correlation showed that increased healthy houses was positively correlated with increased tuberculosis findings in children (Table $3)$.

\section{Table 3}

Correlation Results between Coverage of BCG Immunisation and Healthy Houses with Findings of Paediatric Tuberculosis Aged 0-14 Years in East Java Province in 2015-17

\begin{tabular}{lrr}
\hline Paediatric TB & \multicolumn{2}{c}{ BCG } \\
Immunisation & \multicolumn{2}{c}{$\begin{array}{c}\text { Healthy } \\
\text { Houses }\end{array}$} \\
\hline $\begin{array}{l}\text { Pearson } \\
\text { Correlation }\end{array}$ & 0,67 & 0,63 \\
Sig.(2-tailed) & & \\
$N$ & 0,01 & 0,01 \\
& 38 & 38 \\
\hline
\end{tabular}

\section{DISCUSSION}

Findings of Paediatric Tuberculosis Aged 0-14 Years in Each District/City of East Java Province in 2015-17

Paediatric tuberculosis is a direct infectious disease caused by Mycobacterium tuberculosis, which often attacks everyone. Risk factors for TB transmission that attack adults depend on the length of TB germ exposure and the level of transmission and immunity. These risk factors were also found in children diagnosed with tuberculosis (Ministry of Health RI, 2013). Tuberculosis in children aged $0-14$ years can trigger the child's growth, and development becomes unstable and tends to be disturbed, so that children become unhealthy and can even die if not treated immediately (Febrian, 2015). Research on the epidemiology of tuberculosis in many parts of the world has shown that there are quite a lot of factors causing tuberculosis cases, including weak individual immunity, insufficient socioeconomic conditions, poverty, and housing that does not fulfil health requirements (Yustikarini \& Sidhartani, 2015).

The estimated number of TB cases in children is $12 \%$ of the estimated number of all $\mathrm{TB}$ cases 
(incidents). This estimated number is based on 'mathematical modelling' research, which shows that Indonesia is included in the category of 22 countries with a high burden of paediatric TB (Ministry of Health RI, 2013). This indicator illustrates how many paediatric TB cases have been reached by the programme among the estimated existing TB paediatric cases. This indicator also shows the good performance of the programme, which found a large number of TB cases in children.

The most tuberculosis cases in children in 2017 in East Java Province were found in Surabaya City with 363 cases, Jember District with 290 cases, and Pasuruan District with 178. However, over the same period, were no (0) cases of child tuberculosis found in Nganjuk District and Madiun District. Surabaya City is a densely populated area of East Java when compared to Nganjuk District and Madiun District, which both have low population density (East Java Provincial Health Office, 2018). TB disease in adults and children can spread widely in areas with dense populations (Budi, Ardillah, Sari, \& Septiawati, 2018). High population density will place residents at risk of disease transmission, and it can increase exposure to sufferers of respiratory infections (Kenedyanti \& Sulistyorini, 2017).

The findings of paediatric tuberculosis aged 0-14 years were quite high in East Java, thus encouraging the government to tackle these health problems with various programmes. One programme proposed included a preventive programme for paediatric TB that was promotive and involved active early detection to find tuberculosis sufferers at all levels of the population, as well as to make regularly administer medication until recovery. The findings of paediatric TB can be through passive and active efforts. Efforts to passively detect TB in children were carried out in children who have symptoms or clinical signs of TB coming to health services. Efforts to find paediatric TB cases from an early age include active promotion activities based on family and community who are in close contact with TB patients (East Java Provincial Health Office, 2018).

\section{Correlation between Coverage of BCG Immunisation with Findings of Paediatric Tuberculosis Aged 0-14 Years in East Java Province}

This research showed that there was a correlation between the coverage of BCG immunisation with the findings of paediatric tuberculosis aged $0-14$ years. The national immunisation programme by type of implementation consisted of routine immunisation, supplementary immunisation, and choice immunisation (Ministry of Health RI, 2013). BCG immunisation was included in the routine immunisation programme. Giving BCG immunisation was done to prevent the occurrence of severe TB. This immunisation was given as only one-time immunisation to children under the age of 3 years. East Java Province was one of the regions in Indonesia with full basic immunisation coverage above the national target for the period 2014-2017 (East Java Provincial Health Office, 2018).

In 2017 there was a decrease in complete basic immunisation coverage by $96.70 \%$. An indicator of success in the immunisation programme is the coverage of UCI (Universal Child Immunisation) Village, said to reach the national target if $\geq 80 \%$ of the total infants in the village have received complete basic immunisation. The national target of the UCI Village in 2015 was $84 \%$ and in 2019 it was $29 \%$ (Ministry of Health RI, 2018). The coverage of the BCG immunisation programme in East Java was increasing every year and most regions in East Java have high coverage of BCG immunisation, which was $\geq 80 \%$ in 2017 . The average coverage of BCG immunisation in districts/cities in East Java Province in 2017 was already high, which was above 90\%. Other districts such as Pacitan District, Malang District, and Bangkalan District were still above $83 \%$, while Sampang District was the district with the lowest coverage of BCG immunisation in East Java Province, which was still $57 \%$ in 2017 . The recording and reporting of provincial-level immunisation coverage was a compilation of results reporting immunisation from all districts/cities, which was carried out every month, in addition to the vaccination and goods immunisation record (East Java Provincial Health Office, 2018).

Research conducted by Riani \& Machmud (2018) showed that one of the main strategies for preventing tuberculosis was through administering the BCG vaccine. The effectiveness resulting from the BCG vaccine in Sukabumi City showed that government programmes implemented according to standards played a role in increasing the coverage of other programmes related to targets such as mothers and children. Research conducted by Siregar, Gurning, Eliska, \& Pratama (2018) also showed that infants and toddlers who are not given BCG immunisation are more at risk of 
developing pulmonary TB than children who are given BCG immunisation. According to Susanto, Wahani, \& Rompis (2016), an immunisation development programme by the Ministry of Health of the Republic of Indonesia on the administration of BCG immunisation was carried out with the aim of giving BCG immunisation to infants aged $0-2$ months and giving $B C G$ vaccines to infants aged $>2$ months. The administration of BCG immunisation was very effective as a prevention of other tuberculosis, namely miliary tuberculosis and meningitis tuberculosis, which was suspected to attack both children and adults. Rachim (2017) stated that BCG immunisation was a preventive measure that could prevent pulmonary tuberculosis in children when administered early.

Research conducted by Halim, Naning, \& Satrio (2015) showed that administering a BCG vaccine as an immunisation in children will increase immunity and body immunity. Increased immunity can form immunity in the body or control TB germs in the body because even if the child's status was immunised, TB germs can still enter the body. According to Bakhtiar (2016), BCG storage that would be used as a vaccine should be stored at $2-8^{0} \mathrm{C}$, and in a cool place far from the sun and not frozen. Research conducted by Puspitasari, Saraswati, \& Hestiningsih (2015) also showed that the success of BCG vaccine can be influenced by vaccine effectiveness - namely, quality, dosage, duration of storage, and administration procedures.

Immunisation programme efforts in the effectiveness of high coverage of BCG immunisation record in each district/city will continue to increase, which is also in line with the high findings of child TB in the district/city.

\section{Correlation between Coverage of Healthy Houses with Findings of Paediatric Tuberculosis Aged 0-14 Years in East Java Province}

This research showed that there was a correlation between coverage of healthy houses with tuberculosis findings in children aged 0-14 years. The environmental sanitation programme had several aspects assessed, including access to quality (decent) drinking water, drinking water providers, access to healthy toilets, Community Based Total Sanitation Village (STBM), Public Places (TTU) and Food Management Sites (TPM) and one of them was a healthy house (East Java Provincial Health Office, 2018). Research by Kenedyanti \& Sulistyorini (2017) showed that the physical condition of the house, assessed as a whole and including components such as occupancy density, temperature, humidity, ventilation, walls, floors, and lighting carried risks in transmission and spread of disease. The parameters of the house assessed in a healthy house valuation included three groups of assessment components consisting of housing components, sanitation facilities, and occupant behaviour. In 2016 the majority of houses that had been developed in East Java Province had fulfilled the requirements for healthy houses $(57,43 \%)$. This number increased in 2017 to $69.34 \%$. Coverage of healthy houses programme assessment was the number of houses that fulfilled health requirements in the previous year plus healthy houses from IS/IKL results this year, divided by the number of existing homes and multiplied by $100 \%$, with a target in 2017 of $75 \%$; this target was up compared to the previous year, which was $73 \%$. Indicators of success in environmental health such as healthy houses include input, process, and output. Input indicators include adequate personnel, facilities and infrastructure, and funds. Process indicators refer to implementation of the programme according to guidelines and regulations, and output indicators relate to adjusting the programme targets annually. Each district/city in increasing the coverage of healthy houses in East Java had several activities including community empowerment using participatory methods and TMND (TNI Manunggal Entering Village). This involved giving a stimulant that, the previous year, had been given to underprivileged citizens at high risk of environmental-based diseases (East Java Provincial Health Office, 2018).

Triharinni \& Isvandiari (2014) showed that one component of a healthy house, namely high occupancy density, had a risk of communicable diseases, and if the occupancy density was low, the spread of the disease would be low. With high occupancy density, it only required one person in the household to be infected with TB and not tested regularly for the disease to spread fast. Research conducted by Mudiyono, Wahyuningsih, \& Adi (2015) showed that unhealthy physical environmental factors can trigger germs that cause disease, which will infect residents of the house. Research by Sejati \& Sofiana (2015) showed that one of the criteria for a healthy houses was occupancy density but occupancy density was not the only criterion that was measured; there were several other criteria.

The results of this research also showed that the strength of the correlation between coverage of 
healthy houses with the findings of child tuberculosis was strong and the direction of linear correlation was positive. Table 3 shows that high coverage of healthy houses was positively correlated with the findings of child tuberculosis, which was also high in the year of East Java in 2015-17.

\section{Research Limitations}

These were research limitations in writing and conducting this research, namely the independent variables and the dependent variable in this research were in the form of aggregate data, which were the findings of paediatric tuberculosis, coverage of BCG immunisation, and coverage of healthy houses taken from the East Java Provincial Health Profile in 2015-17. The author just conducted research related to correlation looking for correlation between the dependent variable and the independent variables with statistics.

\section{CONCLUSION}

The findings of paediatric tuberculosis in children aged $0-14$ years during the three years 2015 to 2017 in East Java Province increased, with the highest findings in the city of Surabaya. Coverage of BCG immunisation and coverage of healthy houses in East Java Province also increased during 2015-17.

There was a correlation between coverage of BCG immunisation and coverage of healthy houses with the findings of paediatric TB in East Java in 2015-17. The strength of the correlation between coverage of BCG immunisation and coverage of healthy houses with the findings of paediatric $\mathrm{TB}$ was strong with a positive correlation direction. Due to this correlation, the coverage of $\mathrm{BCG}$ immunisation and the high coverage of healthy houses in each district/city correlated with the findings of paediatric TB, which also increased in each district in East Java.

\section{ACKNOWLEDGEMENT}

The author expresses gratitude towards Dinas Kesehatan Provinsi Jawa Timur as data processor and provider for the purposes of this research and to those who provided support and motivation in the preparation of the research.

\section{REFERENCES}

Bakhtiar. (2016). Tuberculosis diagnosis approach for children in health care facilities with limited facilities. Jurnal Kedokteran Syiah Kuala, 16(2), 122-128.

Budi, I. S., Ardillah, Y., Sari, I. P., \& Septiawati, D. (2018). Analysis of risk factors for tuberculosis in Palembang slum communities. Jurnal Kesehatan Lingkungan Indonesia, 17(2), 87-94. https://doi.org/10.14710/jkli.17.2.87-94

East Java Provincial Health Office. (2018). East Java Province health profile in 2017. Dinas East Java Provincial Health Office. Surabaya.

Febrian, M. A. (2015). Factors related to the incidence of pulmonary TB in children in the area of the Garuda Health Centre in Bandung. Jurnal Ilmu Keperawatan Unversitas BSI Bandung, 3(2), 64-79.

Halim, Naning, R., \& Satrio, D. B. (2015). Risk factors for the incidence of pulmonary TB in children aged 1-5 years in Kebumen District. Jurnal Penelitian Universitas Jambi Seri Sains, 17(2), 26-39.

Kenedyanti, E., \& Sulistyorini, L. (2017). Analysis of mycobacterium tuberculosis and physical condition of the house with incidence pulmonary tuberculosis. Jurnal Berkala Epidemiologi, 5(2), 152-162. https://doi.org/10.20473/jbe.v5i2.2017.152162

Ministry of Health RI. (2013). Technical guidelines for pediatric TB management. Jakarta: Kementerian Kesehatan RI.

Ministry of Health RI. (2018). Indonesia's health profile in 2017. Ministry of Health RI. Jakarta.

Mudiyono, Wahyuningsih, N. E., \& Adi, M. S. (2015). The relationship between maternal behavior and the physical environment of the home with the incidence of pulmonary tuberculosis in Pekalongan City. Jurnal Kesehatan Lingkungan Indonesia, 14(2), 4550.

Puspitasari, R. A., Saraswati, L. D., \& Hestiningsih, R. (2015). Factors related to the incidence of tuberculosis in children (study at the Semarang Public Lung Health Center). Jurnal Kesehatan Masyarakat (e-Journal), 3(1), 191-197.

Rachim, R. D. A. (2017). The relationship of BCG immunisation with the incidence of tuberculosis in children in Pandian Health Center, Sumenep Regency. Saintika Medika, 10(2), 109-114.

https://doi.org/10.22219/sm.v10i2.4158

Riani, R. E. S., \& Machmud, P. B. (2018). Cases control the relationship of BCG 
immunisation with the incidence of pulmonary TB in children in 2015-2016. Sari Pediatri, 19(6), 321-327. https://doi.org/10.14238/sp19.6.2018.321-7

Rosandali, F., Aziz, R., \& Suharti, N. (2016). Relationship between BCG vaccine scar formation and the incidence of tuberculosis infection. Jurnal Kesehatan Andalas, 5(2), 381-384.

Sejati, A., \& Sofiana, L. (2015). Tuberculosis Factors. Jurnal Kesehatan Masyarakat, 10(2),

122-128. https://doi.org/10.15294/kemas.v10i2.3372

Siregar, P. A., Gurning, F. P., Eliska, E., \& Pratama, M. Y. (2018). Analysis of factors associated with pulmonary tuberculosis incidence of children in Sibuhuan General Hospital. Jurnal Berkala Epidemiologi, 6(3), 268-275.

https://doi.org/10.20473/jbe.v6i32018.268275

Susanto, C. K., Wahani, A., \& Rompis, J. (2016). The relationship between BCG immunisation and the incidence of pulmonary $\mathrm{TB}$ in children in the Tuminting Health Center for the period January 2012 - June 2012. Jurnal E-Clinic (ECl), 4(1), 1-5.

Triharinni, T., \& Isvandiari, M. A. (2014). Analysis factor associated tuberculin test in children cintact tuberculosis history. Jurnal Berkala Epidemiologi, 2(2), 151-160.

WHO. (2018). Global tuberculosis report. World Health Organization. Geneva. https://doi.org/ISBN 978-92-4-156564-6

Yani, D. I., Fauzia, N. A., \& Witdiawati. (2018). Factors related to TB in children in Garut Regency. Jurnal Keperawatan BSI, 6(2), $105-112$.

Yustikarini, K., \& Sidhartani, M. (2015). Risk factors for tuberculosis in children infected with mycobacterium tuberculosis. Sari Pediatri, 17(16), 136-140. 